\title{
RADIOCARBON DATING OF TRAVERTINE DEPOSITS, ARBUCKLE MOUNTAINS, OKLAHOMA
}

\author{
DUŠAN SRDOČ \\ Ruđer Bošković Institute, P O Box 1016, 41001 Zagreb, Yugoslavia \\ HENRY CHAFETZ and NANCY UTECH \\ Department of Geosciences, University of Houston \\ Houston, Texas 77004
}

\begin{abstract}
Travertine deposits occur abundantly at past and present sites of waterfalls in the Arbuckle Mountains region of Oklahoma. This area $\left(1600 \mathrm{~km}^{2}\right)$ consists of folded and faulted Prepaleozoic and Paleozoic rocks, with abundant outcrops of Paleozoic carbonate rocks. Samples of recently deposited and old travertine from the Turner Falls area were collected during a 1987 field trip and analyzed for ${ }^{13} \mathrm{C},{ }^{14} \mathrm{C}$ and ${ }^{18} \mathrm{O}$ content. The aquatic chemistry of travertine depositing creeks was investigated systematically and compared with those of similar areas in $\mathrm{SE}$ and central Europe.
\end{abstract}

\section{INTRODUCTION}

${ }^{14} \mathrm{C}$ dating of old solidified travertine which forms the Turner Falls dam revealed a pre-Holocene deposit, beyond ${ }^{14} \mathrm{C}$ dating limits. Freshly deposited calcareous mud contains ca $110 \%$ modern carbon, part of which is due to bomb-produced ${ }^{14} \mathrm{C}$. The negative $\delta^{13} \mathrm{C}$ values of calcareous deposits of carbonate bedrock prove that part of the carbon in travertine is of biogenic origin, thus making ${ }^{14} \mathrm{C}$ dating feasible. Samples of recent calcareous deposits contains a large proportion of calcite depositing micro-organisms, especially Oocardium stratum, indicating biogenically induced precipitation of calcite.

\section{GEOLOGIC SETTING}

The travertine deposits comprising this study lie within the Arbuckle Mountains of south-central Oklahoma (Fig 1). The area, ca $1600 \mathrm{~km}^{2}$, consists of an inlier of folded and faulted Prepaleozoic and Palozoic rocks juxtaposed between the Wichita Mountains to the west and the Ouachita Mountains to the east. Geologically, the Arbuckle Mountains are most widely recognized for substantial outcrops of Paleozoic carbonate rocks exposed as a result of a tumultuous past. Roadcuts along US Interstate 35 between Davis and Ardmore attest to this eventful history as the strata stand in a nearly vertical position.

The $3.5 \mathrm{~km}$ of Cambrian through Devonian strata comprise the largest exposed area of this sequence in the southern midcontinent region, with sizeable exposures of Prepaleozoic granites, Cambrian rhyolites, and Pennsylvanian conglomerates (Ham, 1973).

The massive accumulation of Paleozoic carbonate rocks, in particular the Ordovician Arbuckle Group, is significant with respect to the travertine deposits. As meteoric water seeps down through crevices into this stratum, the water becomes charged with ions (including $\mathrm{Ca}^{2+}, \mathrm{Mg}^{2+}$ and $\mathrm{HCO}_{3}^{-}$) derived from dissolution of the limestone. This ionically charged water 


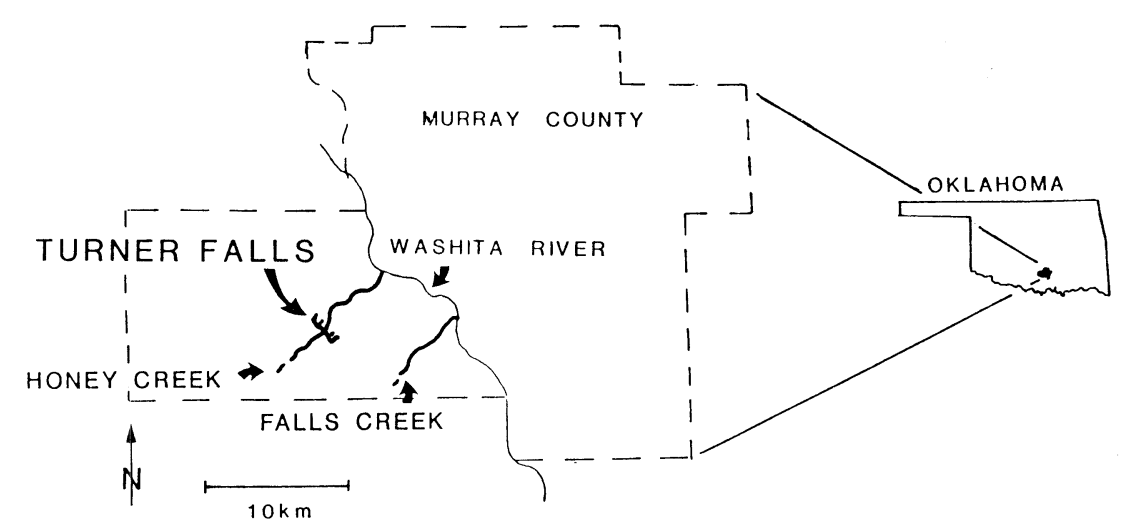

Fig 1. Location of study site

moves underground along faults and eventually emerges as springs, which feed the streams from which the travertine precipitates.

The travertine deposits of Turner Falls show a very pronounced similarity in morphology with travertine of Czechoslovakia and Yugoslavia. The aquatic chemistry of travertine-depositing streams and the isotopic content of calcareous deposits from the Turner Falls area are compared with those of Plitvice National Park in Yugoslavia and of Česki Kras in Chechoslovakia.

\section{CLIMATE}

The Arbuckle Mountains are situated near the western edge of the humid, subtropical climatic zone and the eastern edge of the semi-arid climatic zone (Steila, Wilms \& Leahy, 1981; Jackson \& Hudman, 1982). Annual mean precipitation is $95 \mathrm{~cm}$; monthly mean precipitation is highest in April, May and September and lowest in January and February (Robinson \& Curtis, 1968). The annual mean temperature is ca $17^{\circ} \mathrm{C}$; the daily mean temperature is highest from June through August $\left(\mathrm{ca} 27^{\circ} \mathrm{C}\right.$ ) and lowest from December through February $\left(\mathrm{ca} 7^{\circ} \mathrm{C}\right.$ ) (Robinson \& Curtis, 1868).

\section{ISOTOPIC MEASUREMENTS}

The number of analyzed samples of travertine from Turner Falls was rather modest, when compared with $>500$ analyzed samples from Europe. We first analyzed stable isotopes $\left({ }^{13} \mathrm{C},{ }^{18} \mathrm{O}\right.$ and $\left.{ }^{14} \mathrm{C}\right)$ of recent soft calcareous deposits and old solidified travertine to determine the origin and the datability of the travertine. We conducted our work at the Jožef Stefan Institute (Ljubljana) and Ruđer Bošković Institute (Zagreb), respectively.

As opposed to travertines deposited from freshwater around orifices of (often hot) springs, which do not contain measurable concentrations of ${ }^{14} \mathrm{C}$ and have $\delta^{13} \mathrm{C}$ close to the aquifer matrix value, samples of recent travertine from the Turner Falls area contain a significant concentration of ${ }^{14} \mathrm{C}$ and are depleted in ${ }^{13} \mathrm{C}$ vs the PDB standard. Therefore, the Arbuckle Travertine belongs to the same group as in Yugoslavia (Srdoč et al, 1987) and Czechoslovakia (Horvatinčić et al, 1989). Both ${ }^{13} \mathrm{C}$ and ${ }^{14} \mathrm{C}$ analyses confirmed that part of the carbon in the Turner Falls travertine is of biogenic origin in accor- 
dance with the assumed mechanism of dissolution and subsequent precipitation of calcium carbonate (Srdoč et al, 1985; Emeis, Richnow \& Kempe, 1987).

The $\delta^{18} \mathrm{O}$ values from Turner Falls travertine clustered ca $-5.0 \pm 0.6 \%$ $v s$ PDB. The difference between the old and the recent travertine $\delta^{18} \mathrm{O}$ values was $0.8 \%$ indicating fairly constant climatic and hydrologic conditions during the calcite precipitation periods. The influence of climate on the chemistry of carbonate groundwater has been studied extensively (Drake \& Wigley, 1975; Drake, 1983) as well as the seasonal fluctuations in chemistry of springwater in karst (Srdoč et al, 1985) and limestone areas (Shuster \& White, 1971). Whereas seasonal fluctuations in chemical and isotopic composition of springwater do not influence the ${ }^{14} \mathrm{C}$ age of large samples of travertine $(\sim 50-100 \mathrm{~g})$ needed for conventional ${ }^{14} \mathrm{C}$ dating, long-term changes of climate may introduce an error in ${ }^{14} \mathrm{C}$ age calculation commensurate with the change of ${ }^{14} \mathrm{C}$ activity of groundwater at the time of formation of calcareous deposit. According to $\delta^{18} \mathrm{O}$ values, no major changes in isotopic composition of groundwater occurred during the Holocene; thus, we consider ${ }^{14} \mathrm{C}$ dating of travertines from that period quite reliable, as opposed to old, preglacial travertines. In the latter case, several factors, such as unknown groundwater ${ }^{14} \mathrm{C}$ activity, contamination of samples with recent carbonates and low ${ }^{14} \mathrm{C}$ activity of old samples in general, render ${ }^{14} \mathrm{C}$ dating of old travertines unreliable and sometimes even misleading (Horvatinčić $e t$ $a l, 1986)$. In such cases, the ${ }^{230} \mathrm{Th} /{ }^{234} \mathrm{U}$ dating method may help, providing that adequate samples of clean crystallized calcite embedded in a travertine matrix can be found, and assuming that both travertine and crystallized calcite (eg, in the form of flowstone) were formed within a short period compared to the age of the travertine matrix.

The measured $\delta^{13} \mathrm{C}$ values of old and recent travertine ranged between $-7.0 \%$ and $-7.8 \%$ vs PDB standard. The more negative $\delta^{13} \mathrm{C}$ values of carbonate bedrock stem from the contribution of biogenically evolved $\mathrm{CO}_{2}$ from the topsoil, which has $\delta^{13} \mathrm{C}$ equal to vegetation ( $-24 \%$ for $\mathrm{C} 3$ plants). The dissolution of mineral carbonates $\left(\delta^{13} \mathrm{C}=0.0 \pm 1 \ldots 3 \%\right.$ vs $\left.\mathrm{PDB}\right)$ by $\mathrm{H}_{2} \mathrm{CO}_{3}$ derived from decomposed plant detritus in the topsoil $\left(\delta^{13} \mathrm{C}-24 \%\right.$ vs $\left.\mathrm{PDB}\right)$ results in an intermediate $\delta^{13} \mathrm{C}$ value of dissolved inorganic carbon (DIC) in groundwater. Subsequent precipitation of calcite in the form of travertine does not significantly change isotopic content of the precipitate.

The variable content of ${ }^{13} \mathrm{C}\left(\delta^{13} \mathrm{C}=-7.1 \ldots-12.8 \%\right)$ and ${ }^{14} \mathrm{C}$ $(82 \ldots 113 \%$ modern) for travertines shown in Table 1 reflects the extent of the dissolution-exchange process during the seepage of precipitation water, as described by Mook (1976). In principle, the $\delta^{13} \mathrm{C}$ values and chemical data listed in Table 1 can be used to calculate the initial activity of deposited travertine (Tamers, 1967; Pearson \& Hanshaw, 1970; Mook, 1976; Fontes, 1983). However, the exchange between the dissolved $\mathrm{CO}_{2}$ in groundwater and the atmospheric $\mathrm{CO}_{2}$ in the cavernous karstic underground often renders these calculations useless as shown by Krajcar-Bronić et al (1986). Thus, we did not attempt to calculate the initial activity of travertines. For a detailed study of physico-chemical and isotopic processes that occur in ground and surface waters, the reader is referred to Wigley, Plummer and Pearson (1987) and Dandurand et al (1982). 


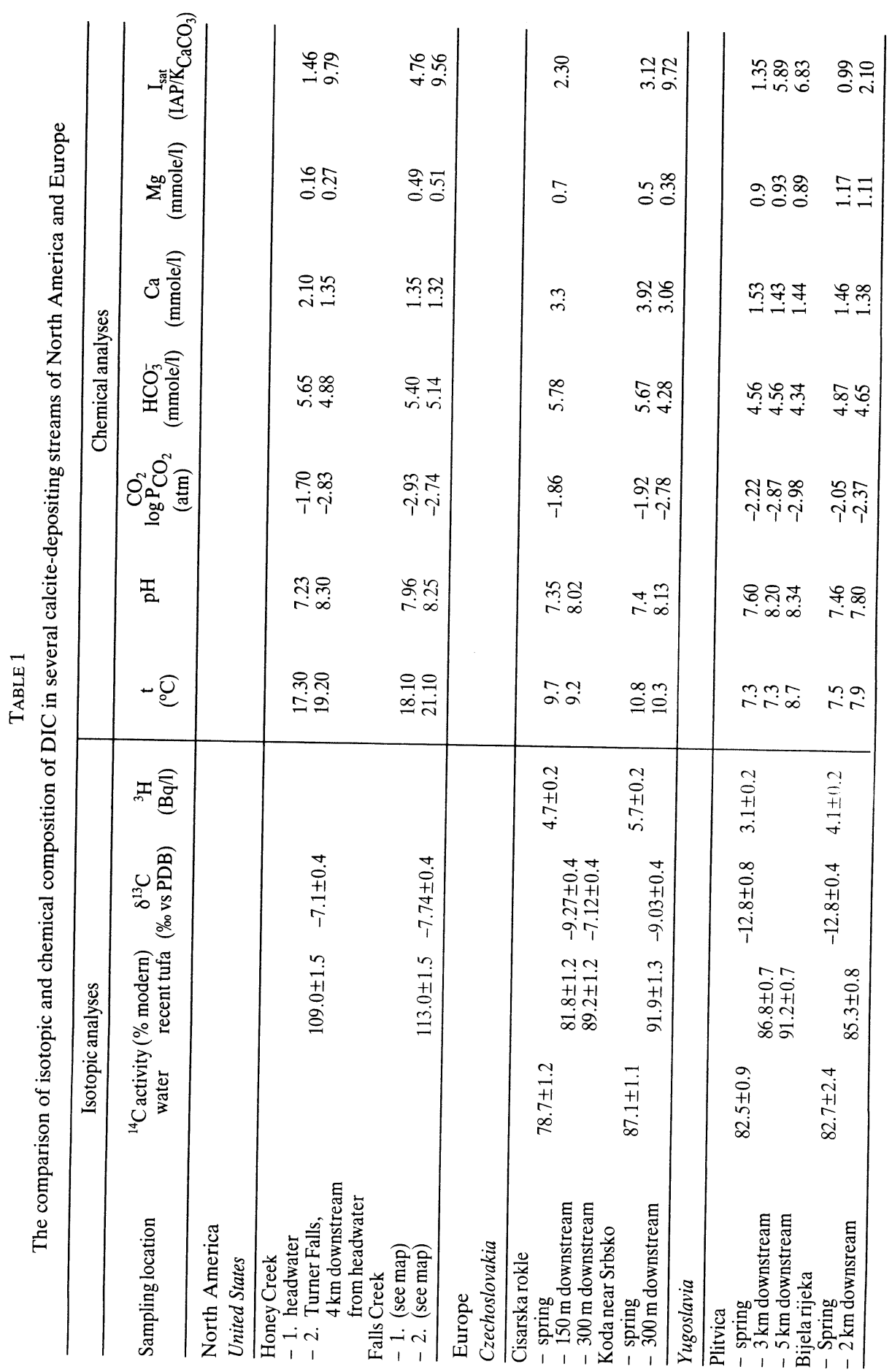


The ${ }^{14} \mathrm{C}$ activity of recently deposited calcite from Honey Creek substantiated the conclusion about the biogenic origin of travertine. The ${ }^{14} \mathrm{C}$ activity ranged from 109-113 pMC, part of which should be attributed to bomb-produced ${ }^{14} \mathrm{C}$ in the atmosphere. ${ }^{14} \mathrm{C}$ was incorporated in travertine in much the same way as ${ }^{13} \mathrm{C} .{ }^{14} \mathrm{C}$ dating of travertine is made possible by its radioactive decay within the time scale of the method (Srdoč et al, 1980).

The initial ${ }^{14} \mathrm{C}$ activity of recently deposited calcite is distorted by bombproduced ${ }^{14} \mathrm{C}$ and cannot be used for age correction of older travertine. This correction - usually of the order of one up to several thousand years becomes less significant for very old samples. It turned out that the age of solid travertine from the Turner Falls barrier exceeds the lower limit of the ${ }^{14} \mathrm{C}$ dating method where any age correction is irrelevant. The true age of the formation of the Turner Falls travertine barrier cannot be determined by ${ }^{14} \mathrm{C}$ dating. By analogy with similar travertine deposits in Europe (Srdoč et al, 1985) this pre-Holocene barrier was most likely built during the last interglacial.

\section{PHYSICO-CHEMICAL CONDITIONS FOR CALCITE PRECIPITATION}

The concurrent studies of travertine (or tufa) formation in Yugoslavia (Srdoč et al, 1985) and Czechoslovakia (Horvatinčić et al, 1989) resulted in relatively well-defined physico-chemical conditions for calcite precipitation in freshwater. Basically, the following conditions were satisfied at all sites in karst areas of both countries where calcite was copiously precipitated in the form of tufa or lake sediment:

1) The water must be supersaturated with calcium carbonate; the saturation index $\left(I_{\text {sat }}=\mathrm{IAP} / \mathrm{K}\right)$ must exceed 3 . Most streams and lakes where intensive precipitation of calcite occurs have saturation indexes of 5-7.

2) The $\mathrm{pH}$ value must be over 8.0 ; mostly, the $\mathrm{pH}$ is between $8.2-8.4$ at locations of intensive calcite precipitation.

3) The concentration of dissolved carbon (DOC), consisting in non-polluted waters mostly of humic and fulvic acids, must not exceed several mg/L of carbon.

The increase of $\mathrm{I}_{\mathrm{sat}}$ accompanied by the rise of $\mathrm{pH}$ is a consequence of $\mathrm{CO}_{2}$ outgassing (Herman, 1987). According to our observations, the actual precipitation of calcium carbonate does not occur spontaneously. Recent research (Chafetz \& Folk, 1984; Srdoč et al, 1985; Emeis, Richnow \& Kempe, 1987) showed that biota play a decisive role in travertine buildup, as well as in nucleation of calcite crystals which form lake sediments. Travertine from Plitvice National Park, Yugoslavia, contains numerous species of diatoms, whereas a sample of recently deposited mud from Honey Creek is composed of calcareous remains of Oocardium stratum.

The reasons calcite precipitation stopped despite persistent supersaturation along the water course in the lowland areas remain obscure. We found that all streams in which calcite does not precipitate despite high $\mathrm{I}_{\text {sat }}$, share a common feature: their DOC level is several times higher (up to 10) than the DOC in carbonate-precipitating waters. This was demonstrated by DOC measurements along the Korana River in Yugoslavia (Srdoč et al, 1985), where abundant calcite precipitation ceased near the point where DOC con- 
centration reached $10 \mathrm{mg} / \mathrm{L}$, the other parameters $\left(\mathrm{I}_{\text {sat }}, \mathrm{pH}\right)$ remaining essentially constant. Due to the short course of travertine-depositing creeks, this phenomenon was not confirmed in Turner Falls. It is assumed that a high level of DOC inhibits the precipitation of calcite in a way similar to that observed in a marine environment (Chave \& Suess, 1970).

Chemical analyses of stream water of calcite-precipitating creeks in the Arbuckle Mountains (Honey Creek, Falls Creek) showed a remarkable similarity, as far as conditions for calcite precipitation are concerned, with calcite-precipitating streams of SE and central Europe. A comparison is given in Table 1, showing results of isotopic analyses, in situ measurements of temperature and $\mathrm{pH}$, concentrations of major ionic species and the calculated

TABLE 2

The comparison of predicted and observed calcite precipitation from streamwaters at several sites in North America and Europe

\begin{tabular}{|c|c|c|c|c|c|}
\hline \multirow{3}{*}{$\begin{array}{l}\text { Sampling location } \\
\text { North America } \\
\text { United States }\end{array}$} & \multirow[t]{3}{*}{$\mathrm{pH}$} & \multirow{3}{*}{$\mathrm{I}_{\mathrm{sat}}$} & \multirow{3}{*}{$\begin{array}{l}\mathrm{DOC}^{*} \\
(\mathrm{mg} / \mathrm{L})\end{array}$} & \multirow{2}{*}{\multicolumn{2}{|c|}{$\begin{array}{c}\text { Calcite precipitation** } \\
\text { (in form of tufa or travertine) } \\
\text { Predicted } \quad \text { Observed }\end{array}$}} \\
\hline & & & & & \\
\hline & & & & & \\
\hline $\begin{array}{l}\text { Honey Creek } \\
-1 \text {. Headwater } \\
\text { - 2. Turner Falls, } \\
4 \text { km downstream } \\
\text { from headwater }\end{array}$ & $\begin{array}{l}7.23 \\
8.30 \dagger\end{array}$ & $\begin{array}{l}1.46 \\
9.79 \dagger\end{array}$ & $\begin{array}{l}5.2 \dagger \\
5.2 \dagger\end{array}$ & $\begin{array}{l}\text { No } \\
\text { Yes }\end{array}$ & $\begin{array}{l}\text { No precipitation } \\
\text { Very intensive precipi- } \\
\text { tation }\end{array}$ \\
\hline $\begin{array}{l}\text { Falls Creek } \\
-1 . \text { (see map) } \\
-2 . \text { (see map) } \\
\end{array}$ & $\begin{array}{l}7.96 \\
8.25 \dagger \\
\end{array}$ & $\begin{array}{l}4.76 \dagger \\
9.56 \dagger\end{array}$ & $\begin{array}{l}22.9 \\
2.67 \dagger \\
\end{array}$ & $\begin{array}{l}\text { No } \\
\text { Yes }\end{array}$ & $\begin{array}{l}\text { Weak precipitation } \\
\text { Intensive precipitation }\end{array}$ \\
\hline $\begin{array}{l}\text { Europe } \\
\text { Czechoslovakia }\end{array}$ & & & & & \\
\hline $\begin{array}{l}\text { Koda near Srbsko } \\
\text { - spring } \\
\text { - } 300 \text { m downstream } \\
\end{array}$ & $\begin{array}{l}7.4 \\
8.13 \dagger \\
\end{array}$ & $\begin{array}{l}3.12 \\
9.72 \dagger \\
\end{array}$ & $\begin{array}{l}10 \dagger \\
10 \dagger \\
\end{array}$ & $\begin{array}{l}\text { No } \\
\text { Yes }\end{array}$ & $\begin{array}{l}\text { No precipitation } \\
\text { Precipitation }\end{array}$ \\
\hline Yugoslavia & & & & & \\
\hline $\begin{array}{l}\text { Plitvica } \\
\text { - spring } \\
\text { - } 3 \mathrm{~km} \text { downstream } \\
-5 \mathrm{~km} \text { downstream } \\
\text { from the spring }\end{array}$ & $\begin{array}{l}7.60 \\
8.20 \dagger \\
8.34 \dagger\end{array}$ & $\begin{array}{l}1.35 \\
5.89 \dagger \\
6.83 \dagger\end{array}$ & $\begin{array}{l}2.0 \dagger \\
2.5 \dagger \\
3.5 \dagger\end{array}$ & $\begin{array}{l}\text { No } \\
\text { Yes } \\
\text { Yes }\end{array}$ & $\begin{array}{l}\text { No precipitation } \\
\text { Weak precipitation } \\
\text { Intensive precipitation }\end{array}$ \\
\hline $\begin{array}{l}\text { Bijela rijeka } \\
- \text { spring } \\
-2 \mathrm{~km} \text { downstream } \\
-6 \mathrm{~km} \text { downstream } \\
\text { from the spring }\end{array}$ & $\begin{array}{l}7.46 \\
7.80 \\
8.2 \dagger\end{array}$ & $\begin{array}{l}0.99 \\
2.10 \\
5.1 \dagger\end{array}$ & $\begin{array}{l}2.0 \dagger \\
2.5 \dagger \\
2.5 \dagger\end{array}$ & $\begin{array}{l}\text { No } \\
\text { No } \\
\text { Yes }\end{array}$ & $\begin{array}{l}\text { No precipitation } \\
\text { No precipitation } \\
\text { Intensive precipitation }\end{array}$ \\
\hline
\end{tabular}

* DOC $=$ dissolved organic carbon in water

** Calcite will start to precipitate when $\mathrm{pH}$ and $\mathrm{I}_{\text {sat }}$ exceed a certain level $(8.2$ and 3 , respectively, in temperate zones), and the concentration of DOC is $<10 \mathrm{mg} / \mathrm{L}$

$\dagger$ Denotes conditions favoring calcite precipitation 
index of saturation. The conditions for calcite precipitation may vary slightly from site to site. Table 2 shows a comparison of physico-chemical conditions for calcite precipitation for areas in the US, Czechoslovakia and Yugoslavia.

The differences in $\mathrm{pH}$ and $\mathrm{I}_{\text {sat }}$ values for various sites (Table 2) can be explained by the variability of geomorphologic and especially climatic characteristics of each site, eg, the mean annual temperature is $17^{\circ} \mathrm{C}$ in the Arbuckle Mountains vs $8^{\circ}$ at Plitvice National Park.

\section{CONCLUSIONS}

Although the actual mechanism of calcite deposition (pure chemical or biogenically induced) does not influence the ${ }^{14} \mathrm{C}$ dating of travertine, it is interesting to note that biota played a dominant role in Arbuckle Mountains travertine formation. Algological analysis (Marčenko, pers commun, 1987) revealed that the largest fraction of calcareous deposit consists of calcite encrustion of Oocardium stratum, an alga known for its ability to form a calcite sheath around soft tissue.

Isotopic composition of carbon from travertine confirms biogenic origin of calcite (which makes up $97 \%$ of dry material) and enables ${ }^{14} \mathrm{C}$ dating of travertine within the range of the method. Physico-chemical conditions for calcite precipitation from freshwaters seems to be very stringent, notably the calcite supersaturation and $\mathrm{pH}$.

The role of biota and DOC was prominent. Whereas micro-organisms (mostly algae and cyanobacteriae) serve as nucleation centers, promoting calcite precipitation, a high DOC concentration, $>10 \mathrm{mg} / \mathrm{L}$, inhibits calcite precipitation and subsequent formation of travertine.

\section{ACKNOWLEDGMENTS}

This work was financially supported by the NSF through the US Yugoslav Joint Board for Scientific and Technological Cooperation, Project No. JF 800.

\section{REFERENCES}

Chafetz, H S and Folk, R L, 1984, Travertines: Depositional morphology and the bacterially constructed constituents: Jour Sed Petrol, v 54, p 289-316.

Chave, K E and Suess, E, 1970, Calcium carbonate saturation in sea water: Limnol Oceanog, v $15, \mathrm{p}$ 633-637.

Dandurand, J L, Gout, R, Hoefs, J, Menschel, G, Schott, J and Usdowski, E, 1982, Kinetically controlled variations of major components and carbon and oxygen isotopes in a calcite-precipitating spring: Chem Geology, v 36, p 299-315.

Drake, J J, 1983, The effect of geomorphology and seasonality on the chemistry of carbonate groundwater: Jour Hydrology, v 61, p 223-236.

Drake, J J and Wigley, T M L, 1975, The effect of climate on the chemistry of carbonate groundwater: Water Resources Research, v 11, p 958-962.

Emeis, K C, Richnow, $\mathrm{H} \mathrm{H}$ and Kempe, S, 1987, Travertine formation in Plitvice National Park, Yugoslavia: chemical versus biological control: Sedimentology, v 34, p 595-609.

Fontes, J Ch, 1983, Dating of groundwater, in Guidebook on nuclear techniques in hydrology: Vienna, IAEA, tech rept ser, no. 91, p 285-317.

Ham, W E, 1973, Regional geology of the Arbuckle Mountains, Oklahoma: Geol Soc America Bull, Ann mtg guidebook field trip no. 5, Oklahoma Geol Survey, 56 p.

Herman, J S, 1987, $\mathrm{CO}_{2}$ outgassing and calcite precipitation in Falling Creek, Virginia, USA: Chem Geology, v 62, p 251-262. 
Horvatinčić, N, Srdoč, D, Obelić, B, Krajcar-Bronić, I and O'Malley, P, 1986, The effects of contamination of calcareous sediments on their radiocarbon age, in Stuiver, $\mathrm{M}$ and Kra,

$\mathrm{R} \mathrm{S}$, eds, Internatl ${ }^{14} \mathrm{C}$ conf, 12th, Proc: Radiocarbon, v 22, no. $2 \mathrm{~A}, \mathrm{p}$ 510-514.

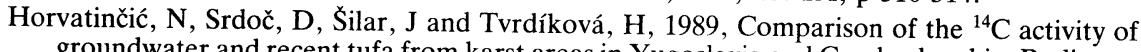
groundwater and recent tufa from karst areas in Yugoslavia and Czechoslovakia: Radiocarbon, this issue.

Jackson, R L and Hudman, L E, 1982, World regional geography: New York, John Wiley \& Sons, Inc, $534 \mathrm{p}$.

Krajcar-Bronić, I, Horvatinčić, N, Srdoč, D and Obelić, B, 1986, On the initial ${ }^{14} \mathrm{C}$ activity of karst aquifers with short mean residence time, in Stuiver, M and Kra, R S, eds, Internatl ${ }^{14} \mathrm{C}$ conf, 12th, Proc: Radiocarbon, v 28 , no. $2 \mathrm{~A}$, p $436-440$.

Mook, W G, 1976, The dissolution-exchange model for dating groundwater with $\mathrm{C}-14$. Interpretation of environmental isotope and hydrochemical data, in Groundwater hydrology: IAEA, Vienna, p 213-225.

Pearson, F J and Hanshaw, B B, 1970, Sources of dissolved carbonate species in groundwater and their effects on C-14 dating, in Isotope Hydrology, Proc: IAEA, Vienna, p 271-285.

Robinson, J L and Curtis, T D, eds, 1968, Oklahoma data book: Norman, Univ Oklahoma, $172 \mathrm{p}$.

Shuster, E T and White, W B, 1971, Seasonal fluctuations in the chemistry of limestone springs: A possible means for characterizing carbonate aquifers: Jour Hydrology, $v 14, p$ 93-128.

Srdoč, D, Horvatinčić, N, Obelić, B and Krajcar-Bronić, I, 1987, Ruđer Bošković Institute radiocarbon measurements IX: Radiocarbon, v 29, no. 1, p 115-134.

Srdoč, D, Horvatinčić, N, Obelić, B, Krajcar-Bronić, I and Sliepčević, A, 1985, Calcite deposition processes in karstwaters with special emphasis on the Plitvice Lakes, Yugoslavia: Carsus Iugoslaviae, v 11/4-6, p 101-204.

Srdoč, D, Obelić, B, Horvatinčić, N and Sliepčević, A, 1980, Radiocarbon dating of calcareous tufa: How reliable data can we expect? in Stuiver, M and Kra, R S, eds, Internatl ${ }^{14} \mathrm{C}$ conf, 10th, Proc: Radiocarbon, v 22, no. 3, p 858-862.

Steila, D, Wilms, D S and Leahy, E P, 1981, Earth and man, a systematic geography: New York, John Wiley \& Sons, Inc, 437 p.

Tamers, M A, 1967, Surface-water infiltration and groundwater movement in arid zones of Venezuela, in Isotopes in hydrology: IAEA, Vienna, p 339-353.

Wigley, T M L, Plummer, L N and Pearson, F J, Jr, 1978, Mass transfer and carbon isotope evolution in natural water systems: Geochim et Cosmochim Acta, v 42, p 1117-1139. 